\title{
Mitochondrial DNA variability and Wolbachia infection in two sibling woodlice species
}

\author{
ISABELLE MARCADÉ, CATHERINE SOUTY-GROSSET, DIDIER BOUCHON, \\ THIERRY RIGAUD \& ROLAND RAIMOND* \\ Université de Poitiers, Laboratoire de Génétique et Biologie des Populations de Crustacés, UMR CNRS 6556, \\ 40 avenue du Recteur Pineau, 86022 Poitiers Cedex, France
}

\begin{abstract}
Several morphological races and subspecies have been described and later included within the terrestrial isopod species Porcellionides pruinosus. During our study of this species, we have worked on specimens from France, Greece, Tunisia and Réunion island. Laboratory crosses have revealed two separate groups of populations: French populations (four localities) in one group, and those from Tunisia, Réunion island and Greece in the other. French individuals were reproductively isolated from those of the other populations. We have undertaken a survey of mitochondrial DNA (mtDNA) polymorphism in these seven populations. We observed two groups of mitotypes corresponding to the two groups of populations. Interfertility experiments between populations and the mitochondrial genetic distances between mitotypes both suggest the presence of two different species, one in France and one in Greece, Tunisia and Réunion island. The two species harbour, respectively, two different Wolbachia lines. Another feature of the molecular genetic analysis was the apparent mitochondrial monomorphism in the French populations and the low variability in the other three populations. The result can be related to the possibility of Wolbachia-induced genetic hitchhiking in these populations.
\end{abstract}

Keywords: laboratory crosses, mitochondrial DNA polymorphism, Porcellionides pruinosus, terrestrial crustacean, Wolbachia.

\section{Introduction}

Porcellionides pruinosus is assumed to be the most widely distributed terrestrial isopod across the world (Vandel, 1960). However, this species has had a complex and confused taxonomic history. Because of their morphological variation, specimens of $P$. pruinosus from Europe and from Africa have been given subspecific rank (Verhoeff, 1918; Strouhal, 1938). Additionally, Garthwaite \& Sassaman (1985) in their studies of North American terrestrial isopods described a new species, Porcellionides floria, for specimens previously included within $P$. pruinosus. They suggest that $P$. pruinosus (as formerly defined) may consist of a number of distinct and localized species rather than one unique cosmopolitan species. We have undertaken a survey of $P$. pruinosus individuals from seven different localities. Different approaches give congruent results, showing the existence of two sibling species.

In parallel with the survey of mitochondrial polymorphism, we have investigated the intensity of Wolbachia

*Correspondence. E-mail: roland.raimond@campus.univ-poitiers.fr

(C) 1999 The Genetical Society of Great Britain. infection in P. pruinosus. The intracytoplasmic Wolbachia bacterium has been found in several species of insects, in crustacean isopods, in mites and in nematodes (Rousset et al., 1992; Bandi et al., 1998). These maternally inherited microorganisms cause cytoplasmic incompatibility in many insects, parthenogenesis in Trichogramma wasps and feminization of genetic males in terrestrial isopods (review in Werren \& O'Neill, 1997). The isopod suborder Oniscidea (woodlice) is strongly affected by the presence of these endocytoplasmic bacteria (Bouchon et al., 1998). Their effect on the control of sex determination has been well studied in Armadillidium vulgare, where Wolbachia is believed to inhibit the activity of 'male genes' by suppressing androgenic gland development (Martin et al., 1973; Juchault et al., 1993). Infected eggs develop into functional females, that can transmit bacteria, regardless of their sex chromosome composition (review in Rigaud, 1997). The main consequence of this cytoplasmic sex determination is distortion of the sex ratio, with infected females producing highly female-biased broods. The same phenomenon also occurs in the woodlouse P. pruinosus (Juchault et al., 1994; Rigaud et al., 1997). In the present study, we found no mtDNA 
polymorphism in the populations entirely infected by the feminizing Wolbachia, but a small amount of variation in mtDNA in populations where Wolbachia infection was incomplete. This is consistent with a reduction in mitochondrial diversity resulting from hitchhiking following the spread of the intracytoplasmic symbiont.

\section{Materials and methods}

\section{Sampling}

The four French populations investigated were from the following locations: Mignaloux (Vienne), Nevers (Nièvre), Poitiers (Vienne) and St Martin-du-Fouilloux (Deux-Sèvres). All gravid females collected from the wild were reared in the laboratory $\left(20^{\circ} \mathrm{C}\right.$; LD: $\left.18: 6\right)$ and sex-ratios of their progenies noted. Specimens from Réunion island, Indian ocean (at St Paul), Greece (Athens) and Tunisia (Tunis) were reared in the same conditions. A scanning microscope survey of cuticular ornaments revealed that individuals from these populations conformed morphologically to the description of the species $P$. pruinosus (Vandel, 1960; Hadley \& Hendricks, 1985) (results not shown).

\section{Interfertility experiments}

Crosses between the different French locations were fully interfertile (data not shown). To test interfertility between individuals from distant locations, males and females from France (St Martin-du-Fouilloux), Greece, Tunisia and Réunion island were combined to obtained 12 interpopulation crosses and four intrapopulation crosses (Table 1). In each crossing type, eight couples of one male and one virgin female were mated under laboratory conditions $\left(20^{\circ} \mathrm{C}, \mathrm{LD} 18: 6\right)$.

Table 1 Number of fertilized Porcellionides pruinosus females out of the eight tested, in crosses involving males and females from different locations

\begin{tabular}{lcccc}
\hline & \multicolumn{4}{c}{ Origin of males } \\
\cline { 2 - 5 } Origin of females & France & Tunisia & Réunion & Greece \\
\hline France & $8 \dagger$ & $1 \dagger$ & 0 & 0 \\
Tunisia & 0 & $8 \dagger$ & $8 \dagger$ & $8 \dagger$ \\
Réunion & 0 & $8 \dagger$ & $8 \dagger$ & $8 \dagger$ \\
Greece & 0 & $8 \dagger$ & $8 \dagger$ & $8 \dagger$ \\
\hline
\end{tabular}

†indicates fertilized females that produced offspring.

findicates fertilized female that produced no offspring (eggs abort).

\section{Mitochondrial DNA analysis}

The total mitochondrial DNA polymorphism was analysed by restriction fragment length polymorphism. As mitochondrial DNA is maternally inherited, offspring from all broods produced by each mother were pooled in isofemale lines. Total mitochondrial DNA was extracted from gonads, nervous tissue and fat body, according to Souty-Grosset et al. (1992). The mtDNA was then digested with the following restriction enzymes: KpnI, AccII, ClaI, BglII, PvuII, HincII, ScaI, EcoRI, BstEII, SstI. Most of them recognize six-base sequences, except $A c c \mathrm{II}$, which recognizes a four-base sequence. The digested DNA patterns were run on agarose gels under the conditions described in Grandjean et al. (1993) and fragment migration patterns were visualized by staining with SYBR Green I FMC (BioProducts). This sensitive fluorescent stain detected as little as $60 \mathrm{pg}$ nucleic acid per band (using $300 \mathrm{~nm}$ transillumination). The number of nucleotide substitutions per site, $d$, was estimated by the method of Nei \& Tajima (1983).

In addition, a PCR-RFLP survey was made on the mitochondrial 16S rDNA (mt 16S rDNA). The total DNA was extracted from each individual's gonads, fat tissue and nervous system, according to Wilson et al. (1985). Amplification of the mt 16S rDNA was carried out according to Kocher et al. (1989) on a thermocycler Trio thermoblock (Biometra). The mixture contained the two primers, 16 SAR and $16 \mathrm{SBR}$, that targeted the mitochondrial 16S ribosomal RNA genes (Simon et al., 1991), and Taq polymerase (Promega Biotech). PCR conditions were described in Bouchon et al. (1994). Amplified portions of $\mathrm{mt} 16 \mathrm{~S}$ rDNA were purified by the chloroform method and digested with the following 11 restriction endonucleases: AccII, HhaI, MspI, RsaI, HaeIII, DraII, SspI, NdeII, TaqI, HinfI and AluI. Digested amplification products were run on $1.5 \%$ agarose gel in TBE buffer for $45 \mathrm{~min}$ at $100 \mathrm{~V}$. After staining with ethidium bromide, fragments were visualized with UV light.

\section{Detection of Wolbachia microorganisms}

The prevalence of Wolbachia has previously been investigated in the Mignaloux and Nevers populations (Rigaud et al., 1997). The prevalence of Wolbachia in the populations from Poitiers, St-Martin-du-Fouilloux, Réunion island, Greece and Tunisia, was determined in wild-caught mothers, when possible, or in two offspring. The bacteria were detected by PCR amplification of part of the bacterial 16S ribosomal DNA gene, using specific primers (99f and 994r) amplifying a 900-bp fragment (O'Neill et al., 1992). The total DNA extraction from 
Table 2 Mitochondrial DNA digestion profiles produced by restriction enzymes in all the populations of Porcellionides pruinosus (band sizes in $\mathrm{kb}$ )

\begin{tabular}{|c|c|c|c|c|c|c|c|c|c|c|c|c|c|c|c|c|c|c|c|c|}
\hline \multicolumn{2}{|c|}{ KpnI } & \multicolumn{2}{|c|}{$A c c \mathrm{II}$} & \multicolumn{2}{|c|}{ ClaI } & \multicolumn{2}{|c|}{$B g / I I$} & \multicolumn{2}{|c|}{$P v u \mathrm{II}$} & \multicolumn{3}{|c|}{ HincII } & \multicolumn{2}{|c|}{ ScaI } & \multicolumn{2}{|c|}{ EcoRI } & \multicolumn{2}{|c|}{ Bst $\mathrm{EII}$} & \multicolumn{2}{|c|}{ Sst $\mathrm{I}$} \\
\hline A & B & A & B & A & B & A & B & A & B & A & B & C & A & B & A & B & A & - & A & B \\
\hline 17.0 & 22.6 & $6.7+$ & 18.4 & 10.6 & 10.2 & $5.4 \dagger$ & 6.0 & 19.6 & 18.6 & 9.2 & 4.2 & 4.2 & 12.2 & 8.6 & 19.0 & 19.0 & 20.0 & 28.5 & 6.6 & 22.4 \\
\hline 11.1 & 11.3 & $3.5+$ & 9.2 & $6.9 \dagger$ & $6.7 \dagger$ & 5.0 & $3.2+$ & 9.8 & 9.3 & 4.6 & $3.9 \dagger$ & $3.1 \dagger$ & $6.6+$ & $5.8 \dagger$ & 9.5 & 9.5 & 10.0 & 14.4 & 5.2 & 11.2 \\
\hline 8.5 & 1.2 & $2.3 \dagger$ & $4.2 \dagger$ & 5.3 & 5.1 & $3.7 \dagger$ & 3.0 & 7.0 & 4.8 & $3.0 \dagger$ & $2.8 \dagger$ & $2.8 \dagger$ & 6.1 & 4.3 & 9.2 & 8.6 & 4.2 & & $4.1 \dagger$ & 5.6 \\
\hline \multirow{9}{*}{5.5} & 0.6 & 1.4 & 1.4 & 3.6 & $1.9 \dagger$ & 3.4 & $1.5 \dagger$ & 3.5 & 2.4 & $2.4 \dagger$ & $2.7 \dagger$ & $2.7 \dagger$ & 2.6 & 2.6 & 4.6 & 4.3 & 2.1 & & $4.0 \dagger$ & 2.8 \\
\hline & $0.3 \dagger$ & 0.7 & 0.7 & 1.8 & 0.8 & 2.5 & $1.2 \dagger$ & $0.7 \dagger$ & $2.3 \dagger$ & 2.2 & 2.1 & 2.1 & 1.3 & $2.6 \dagger$ & & & & $1.9 \dagger$ & & 3.3 \\
\hline & & & & & 0.4 & 1.7 & $1.2 \dagger$ & & & 1.1 & $1.3 \dagger$ & $1.3 \dagger$ & & 1.3 & & & & & 2.6 & \\
\hline & & & & & & $0.8 \dagger$ & $1.0 \dagger$ & & & $0.8 \dagger$ & 0.8 & $0.9 \dagger$ & & & & & & & & \\
\hline & & & & & & & 0.8 & & & $0.7 \dagger$ & $0.7 \dagger$ & 0.8 & & & & & & & & \\
\hline & & & & & & & $0.7 \dagger$ & & & $0.5 \dagger$ & $0.6+$ & $0.7 \dagger$ & & & & & & & & \\
\hline & & & & & & & 0.4 & & & $0.4 \dagger$ & $0.5 \dagger$ & $0.6 \dagger$ & & & & & & & & \\
\hline & & & & & & & & & & & 0.4 & $0.5 \dagger$ & & & & & & & & \\
\hline & & & & & & & & & & & & 0.4 & & & & & & & & \\
\hline \multirow[t]{2}{*}{42.0} & 35.7 & 14.5 & 33.8 & 28.3 & 25.1 & 22.4 & 18.8 & 40.6 & 37.4 & 24.8 & 19.8 & 19.9 & 28.8 & 25.3 & 42.3 & 41.4 & 38.3 & 42.9 & 25.9 & 42.0 \\
\hline & 38.1 & 39.4 & 42.2 & 42.1 & 42.1 & 42.0 & 36.2 & 42.0 & 42.0 & 40.2 & 41.3 & 41.4 & 42.0 & 42.0 & & & 42.0 & & 42.1 & \\
\hline
\end{tabular}

$\dagger$ Bands must be multiplied by three to obtain the real size of the mtDNA molecule. The total size of the mtDNA molecule is given in the last lines of the table: numbers in italics indicate the simple addition of the bands; the numbers in bold indicate the real size according to the trimeric model of Raimond et al. (1999). "_" indicates an enzyme that did not cleave.

Three mitotypes are defined from these profiles: M1 AAAAAAAAAA; M2 BBBBBBBB-B; M3 BBBBBCBB-B

the gonads and the PCR conditions were as described in Bouchon et al. (1998). Amplification products were run on a $1.5 \%$ agarose gel in TBE, stained with ethidium bromide and visualized under UV light.

From two Wolbachia strains (Réunion island and Poitiers), we amplified a fragment of 16S rDNA gene homologous to positions 8-973 of the E. coli sequence, by using $27 \mathrm{f}$ and 973r primers (Rousset et al., 1992). From amplification products, direct double strand sequencing was performed as described by Bouchon et al. (1998). The primers used for sequencing were 27f, 685r, 530f and 973r (Rousset et al., 1992). Using these primers, 812 nucleotide sequences of the rRNA gene were determined on the both strands. The GenBank, EMBL and DDBJ accession numbers for the nucleotide sequences of the two isolate of Wolbachia are AJ133196 (Réunion island) and AJ223242 (Poitiers).

\section{Results}

\section{Interfertility analysis}

As shown in Table 1, there was no interbreeding between French specimens and the others. In these series of crossing no mating behaviour was observed. The reproductive isolation was therefore prezygotic, which was confirmed by the fact that no sperm was found in the females' genital tracts after the experiment. In comparison, individuals from Réunion island, Greece and Tunisia were totally interfertile. Throughout, no distinguishable morphological characters were detected, especially on the male copulatory appendix.

\section{Mitochondrial DNA analysis}

The $P$. pruinosus mtDNA was atypical in size, around $42 \mathrm{~kb}$. The size, and the restriction patterns, were similar to those of the mtDNA from another terrestrial isopod A. vulgare (Raimond et al., 1999). The mtDNA seems to be composed of three identical $14 \mathrm{~kb}$ monomers. One of these is linear, whereas the other two form a circle, with one monomer reversed with respect to the other. A single restriction site per monomer generates a four-band pattern in a restriction profile and additional restriction sites generate three identical fragments leading to a single band (Raimond et al., 1999). These fragments have to be counted triply to obtain a correct estimation of the size of the mtDNA (Table 2).

The RFLP analysis revealed three mitotypes: M1, M2 and M3. There was no mtDNA polymorphism in the four French populations, all the isofemale lines (20 for St Martin, nine for Poitiers, 10 for Nevers and 11 for Mignaloux) having the same mitotype, M1. Mitotype M1 was strictly confined to the French populations and was not found in the Réunion island, Greek and Tunisian populations, whereas M2 and M3 were shared by these last three populations. All of the enzymes exhibited a distinct profile between the mitotype M1 and the two mitotypes M2 and M3. The M2 and M3 
Table 3 Calculated fragment sizes, in number of base pairs, resulting from restriction enzyme digestion of mitochondrial 16S rDNA amplification product for specimens of Porcellionides pruinosus

\begin{tabular}{lcc}
\hline & \multicolumn{2}{c}{ Population } \\
\cline { 2 - 3 } Restriction enzyme & France & Tunisia-Réunion-Greece \\
\hline AluI & $384+111$ & $\mathrm{dnc}$ \\
RsaI & $345+160$ & $345+160$ \\
HhaI & $\mathrm{dnc}$ & $\mathrm{dnc}$ \\
MspI & $362+133$ & $\mathrm{dnc}$ \\
HaeIII & $416+79$ & $373+122$ \\
TaqI & $416+79$ & $416+79$ \\
NdeII & 247 & $\mathrm{dnc}$ \\
AccII & $439+56$ & $439+56$ \\
HinfI & $\mathrm{dnc}$ & $416+79$ \\
DraII & $439+56$ & $\mathrm{dnc}$ \\
Ssp I & $\mathrm{dnc}$ & $\mathrm{dnc}$ \\
\hline
\end{tabular}

dnc, did not cleave.

mitotypes were closely related $(d=0.0092)$. M1 was much more distantly related to each of them $(d=0.4448$ between M1 and M2; and $d=0.4490$ between M1 and M3).

The PCR-RFLP analysis of the mitochondrial ribosomal gene revealed two distinct mitotypes, one for the four French populations and one for the three others. As shown in Table 3, six restriction enzymes out of the 11 distinguish the French mitotypes from the others: AluI, MspI, HaeIII, NdeII, HinfI and DraII. We obtained identical restriction patterns for Tunisian, Greek and Réunion island individuals. The nucleotide distance estimated according to Nei \& Tajima (1983) was 0.133 between the mitotype harboured by the French population and the mitotype harboured by the Réunion island, Tunisian and Greek populations.

\section{Sex ratios, Wolbachia infection and relationship with mtDNA variability}

Analysis of progeny sex ratios showed that females infected with Wolbachia produced female-biased offspring, whereas those that were not infected produced a more balanced sex ratio (Table 4). The differences in the sex ratios of offspring from infected and uninfected females were highly significant in Tunisia $\left(\chi_{4}^{2}=26.22\right.$; $P<0.01)$ and Réunion $\left(\chi_{7}^{2}=60.41 ; P<0.01\right)$, as had been seen in Nevers (Rigaud et al., 1997).

Wolbachia studies in French populations (Rigaud et al., 1997) showed that almost all females in the wild harboured Wolbachia, with one population, Mignaloux, being 100\% infected. Only one uninfected female was found in Nevers (Table 5). Surveys of the Poitiers and St-Martin-du-Fouilloux populations showed that all the females tested were infected with Wolbachia (Table 5), so that $97.4 \%$ of the French females tested harboured Wolbachia. They also all harboured the same mitotype, M1. The other populations of $P$. pruinosus tested had a lower incidence of Wolbachia; the Réunion island and Tunisia populations contained about 60\% infected females (Table 5). The animals from Greece, Tunisia and Réunion island that were infected with Wolbachia had the M2 mitotype, whereas the uninfected ones had the M3 mitotype (Table 4).

The Wolbachia transmission level was also detected by PCR in males and females from the progenies of infected mothers (Table 5). Wolbachia transmission rates are significantly different between populations $\left(\chi_{6}^{2}=33\right.$; $P<0.001)$. A logistic regression, comparing France against Greece, Réunion island and Tunisia, showed significant effects of origin (Wald-test $=9.85 ; \quad P=$ 0.0017 ) and of sex (Wald-test $=14.65 ; \quad P=0.0001$ ). Males of the Greek, Réunion island and Tunisian populations are always uninfected by Wolbachia, whereas in the French population males harbour Wolbachia

Table 4 Wolbachia infection, progeny sex ratios and mitochondrial types in wild-caught females of Porcellionides pruinosus

\begin{tabular}{|c|c|c|c|c|c|c|}
\hline \multirow[b]{2}{*}{ Locations } & \multicolumn{3}{|c|}{ Wolbachia-infected lines } & \multicolumn{3}{|c|}{ Uninfected lines } \\
\hline & $N^{\dagger}$ & $\% \mathrm{~m} \dagger$ & Mitotypes§ & $N$ & $\% \mathrm{~m}$ & Mitotypes \\
\hline Nevers & 94 & $35.6 \pm 2.9-$ & M1 & 19 & 46.4 & M1 \\
\hline St. Martin & 22 & $28.4 \pm 5.1(815)$ & M1 & 0 & & \\
\hline Poitiers & 4 & $22.0 \pm 6(100)$ & M1 & 0 & & \\
\hline Tunisia & 3 & $19.9 \pm 10.8(251)$ & M2 & 2 & $48.3 \pm 2.4(87)$ & M3 \\
\hline Greece & 3 & $8.8 \pm 9.6(80)$ & M2 & 3 & $46.5 \pm 4.3(226)$ & M3 \\
\hline
\end{tabular}

$\dagger$ Number of isofemale lines tested (one mother was at the origin of a given line); tproportion of males in progenies produced by the mothers (the total number of offspring is given in parentheses); §mitochondrial haplotype linked with each mother; $\uparrow$ results from Rigaud et al. (1997). 
Table 5 Wolbachia infestation detected by PCR in wildcaught females of Porcellionides pruinosus and Wolbachia transmission detected by PCR in offspring from infected mothers in various populations (the number of individuals tested is given parentheses)

\begin{tabular}{lclllll}
\hline & & \multicolumn{3}{c}{ Transmission rate } \\
\cline { 3 - 6 } Locations & \multicolumn{2}{c}{ Infestation rate } & \multicolumn{2}{c}{ Males } & \multicolumn{2}{c}{ Females } \\
\hline Mignaloux & $100 \%$ & $(11) \dagger$ & $87.5 \%$ & $(8)$ & $91.6 \%$ & $(12)$ \\
Nevers & $90 \%$ & $(10) \dagger$ & $80 \%$ & $(15)$ & $100 \%$ & $(13)$ \\
St. Martin & $100 \%$ & $(29) \dagger$ & $100 \%$ & $(12)$ & $90.9 \%$ & $(11)$ \\
Poitiers & $100 \%$ & $(4)$ & $100 \%$ & $(9)$ & $100 \%$ & $(10)$ \\
Réunion island & $60 \%$ & $(8)$ & $0 \%$ & $(4)$ & $87.5 \%$ & $(16)$ \\
Tunisia & $62.5 \%$ & $(5)$ & $0 \%$ & $(4)$ & 93.3 & $(15)$ \\
Greece & $60 \%$ & $(10)$ & $0 \%$ & $(2)$ & 92.3 & $(13)$ \\
\hline
\end{tabular}

$\dagger$ Results from Rigaud et al. (1997)

endosymbionts at an equal rate to that of females. On average, $90.9 \%$ of the males from French populations harboured the symbionts, and all the males were infected in Poitiers and St-Martin-du-Fouilloux (Table 5).

Finally, the sequence of the bacterial 16S rRNA genes revealed important differences between Wolbachia strains from geographically distant locations. The Wolbachia strain from Poitiers showed an identical sequence to that of $P$. pruinosus previously published, isolated from Celles sur Belle (France), a locality close to St Martin-du-Fouilloux $(40 \mathrm{~km})$ and Poitiers $(50 \mathrm{~km})$ (Bouchon et al., 1998). The sequence of Wolbachia from Réunion island exhibited differences from French symbionts (Table 6). The two sequences showed a pairwise distance of $2 \%$, which was the highest divergence recorded in oniscidean symbionts (Bouchon et al., 1998). Even if sequence patterns were typical of the B group of Wolbachiae (Werren \& O'Neill, 1997), the high divergence recorded here indicates that the two strains are distantly related.

\section{Discussion}

Over the last few years, many cases of 'species complexes' have been described in isopods: for example, the Orithoniscus flavus complex (Dalens et al., 1996) and the Oniscus asellus complex (Bilton, 1997). Even though the specimens collected in Greece, Réunion island, Tunisia and France were morphologically indistinct and all corresponded to the $P$. pruinosus description, it was clear that they could be separated into two groups. There were no crosses between individuals from France and those from Réunion island, Greece and Tunisia; this reproductive isolation was precopulatory in that no mating occurred. Greek, Réunion island and Tunisian populations were interfertile and genetically closely related. This suggested that these three populations belong to the same species. What has previously been considered to be a single species consists, in fact, of two sibling species. These two species are geographically distinct: one is commonly found in France ('French group' in the following discussion) and the other one was collected in Tunisia, Réunion island and Greece ('southern group' in the following discussion). These two sibling species may be included in a 'Porcellionides pruinosus species complex', but it appears that the taxonomic status of $P$. pruinosus needs re-evaluation on a worldwide basis.

The data from the mitochondrial DNA analysis also strengthen the distinction between two species. Using RFLP analysis of the total mtDNA, we obtained three mitotypes of which one was strictly restricted to the French group. The two remaining mitotypes were shared in the three other populations. The PCR-RFLP analysis of the mt $16 \mathrm{~S}$ rDNA showed two different patterns: one is only found in the French group and the other in the southern group. The mitochondrial diversity in $P$. pruinosus, with a considerable genetic distance $(d \approx 0.45)$ between the 'French' mitotype and the 'southern' mitotypes, suggests great divergence between the two sets of populations. Another line of evidence

Table 6 Sequence comparison of the P. pruinosus symbiont from Réunion island (AJ133196) with known Wolbachia representatives, in 812 bp partial sequence of $16 \mathrm{~S}$ rDNA

\begin{tabular}{lcccc}
\hline Wolbachia strain (origin) & Nucleotide change & Wolbachiae group & Phenotype & Accession number \\
\hline Isopods & & & & \\
$\quad$ Porcellionides pruinosus (Poitiers) & 17 & B & F & AJ223242 \\
Armadillidium vulgare (Angoulême) & 0 & B & F & AJ223238 \\
Porcellio dilatatus petiti (St Honorat) & 9 & B & CI & X65673 \\
Insects & & & & \\
Culex pipiens & 19 & B & CI & X61768 \\
Drosophila simulans (Mont d'Ambre) & 18 & B & CI & X64266 \\
Drosophila simulans (Riverside) & 19 & A & CI & X64264 \\
\hline
\end{tabular}

(c) The Genetical Society of Great Britain, Heredity, 83, 71-78. 
confirming separated species is the nucleotide distance of 0.13 between the mitotypes, obtained with the mt $16 \mathrm{~S}$ RNA gene portion. Tam et al. (1996) observed similar nucleotide distance based on $\mathrm{mt} 16 \mathrm{~S}$ rDNA between different species of the Decapoda genus Emerita: 0.15 between E. analoga and E. talpoida; 0.13 between $E$. analoga and E. portoriciensis; and 0.15 between E. analoga and E. benedicti.

The idea that $P$. pruinosus has been dispersed throughout the world by the actions of man, because similar forms are observed throughout an extensive range, is no longer acceptable. Such a spread may have occurred for the southern group which could have been transported by human activities from Greece or Africa (Tunisia) to Réunion island, even if historical evidence for such an introduction is lacking. The dispersal of the ' $P$. pruinosus complex' may be ancient and may predate the divergence of the sibling species. We propose that the French group has been isolated from its native locality, the Mediterranean region (Vandel, 1960), and has genetically diverged from the southern group. An isolating mechanism has evolved between these two species, so that hybridization is no longer possible between them.

Additionally, the Wolbachia harboured by the French and southern groups of the $P$. pruinosus complex are genetically different. Since both the hosts and Wolbachia strains are different, the differences in feminizing pattern (presence vs. absence in males) and in prevalence between the two associations could result from differences in coevolutionary patterns. Crossinfections are needed to discriminate which partner of the association plays a crucial role in these differences. Nevertheless, the pattern of Wolbachia infection in the southern group of the $P$. pruinosus complex is more closely related to that of Wolbachia infection in A. vulgare, where the males are never infected (Juchault et al., 1993). This is confirmed by the closeness of ribosomal gene sequences of $A$. vulgare and French $P$. pruinosus symbionts.

Variations in mitochondrial DNA are often used to trace the evolutionary history of populations (Avise et al., 1983). However, several selective forces may act on this genetic marker, including parasite-induced selective sweeps, to confound the interpretation of data (Ballard \& Kreitman, 1995). The host reproductive changes caused by Wolbachia enhance the spread of the symbiont in infected populations (Werren \& O'Neill, 1997). As a consequence, the infected cytoplasm increases in frequency by 'hitchhiking', at the expense of uninfected cytoplasm (Turelli et al., 1992). This is very similar to the genetic hitchhiking associated with the fixation of an advantageous mutation by selection (Maynard Smith \& Haigh, 1974) and will usually cause a reduction in genetic polymorphism. Its maternal inheritance and the absence of recombination makes mitochondrial DNA sensitive to such hitchhiking and a maternally inherited factor, such as Wolbachia, could influence haplotype diversity (Ballard \& Kreitman, 1995). Genetic hitchhiking could have caused the pattern of mtDNA variation in $P$. pruinosus. The feminizing effect of Wolbachia imparts a selective advantage to the infected females, which could have lead to a selective sweep of the associated cytoplasm, carried passively as the microorganism spreads through the population. Populations almost entirely infected with Wolbachia (French species) showed no mitochondrial polymorphism, suggesting that the polymorphism had disappeared when invasion was complete. This hypothesis is strengthened by the presence of a unique lineage of symbionts in French populations according to the sequence data. The only uninfected French wild-caught female shared the same mitotype with females infected by the symbiont. This could be caused by a secondary loss of Wolbachia in this female. On the other hand, populations with polymorphism for Wolbachia infection (southern group) had slight mitochondrial polymorphism, and there was a link between Wolbachia infection status and mtDNA types. Here, a single mitotype was associated with the symbionts, which might be explained by a single Wolbachia infection event. In these populations, uninfected individuals showed no mtDNA polymorphism. This might be because of the small size of our samples, and/or bottlenecks experienced by populations.

The general pattern of mtDNA polymorphism and Wolbachia infection in $P$. pruinosus contrasts with that found in another woodlouse: A. vulgare. The mtDNA in $A$. vulgare shows considerable polymorphism, despite the presence of sex ratio distorters including a Wolbachia symbiont (Grandjean et al., 1993; Rigaud et al. unpublished observation). Wolbachia prevalence is always low in A. vulgare populations (Juchault et al., 1993), and another sex ratio distorter is partially paternally inherited. These two traits contribute to the mtDNA polymorphism (Grandjean et al., 1993). Such phenomena were not found in $P$. pruinosus, and the pattern of mitochondrial variation must be related to the strong prevalence of Wolbachia in this complex of species.

\section{Acknowledgements}

We thank M. Caillon for providing the samples from Réunion island and B. Grosset for allowing samples to be taken on his property. This study was financed by a grant from the French Ministère de l'Education 
Nationale de la Recherche et de la Technologie (AccSv3961098).

\section{References}

AVISE, J. C., SHARPIRA, J. F., DANIEL, S. W., AQUADRo, C. F. AND LANSMAN, R. A. 1983. Mitochondrial DNA differentiation during the speciation process in Peromyscus. Mol. Biol. Evol., 1, 38-56.

BALLARD, J. W. O. AND KREITMAN, M. 1995. Is mitochondrial DNA a strictly neutral marker? Trends Ecol. Evol., 10, 485-488.

BANDI, C., ANDERSON, T. J. C., GENCHI, C. AND BlAXTER, M. L. 1998. Phylogeny of Wolbachia in filarial nematodes. Proc. $R$. Soc. B, 265, 2407-2413.

BILton, D. T. 1997. The Oniscus asellus complex (Crustacea: Isopoda: Oniscidea) in the Iberian Peninsula with the description of a new species. Rev. Suisse Zool., 104, 217-227.

BOUCHON, D., SOUTY-GROSSET, C. AND RAIMOND, R. 1994. Mitochondrial DNA variation and markers of species identity in two penaeid shrimp species: Penaeus monodon Fabricius and P. japonicus Bate. Aquaculture, 127, 131-144. BOUCHON, D., RIGAUD, T. AND JUCHAULT, P. 1998. Evidence for widespread infection by Wolbachia endosymbionts in isopod crustaceans: molecular identification and host feminization. Proc. R. Soc. B, 265, 1081-1090.

DALENS, H., ROUSSET, A. AND FOURNIER, D. 1996. Les formes epigées du genre Oritoniscus (Crustacea, Isopoda, Oniscidea). I. Le complexe Oritoniscus flavus. Rev. Suisse Zool., 103, 623-641.

Garthwaite, R. AND SASSAman, C. 1985. Porcellionides floria, new species, from North America; provinciality in the cosmopolitan isopod Porcellionides pruinosus (Brandt). $J$. Crust. Biol., 3, 539-555.

GRANDJEAN, F., RIGAUD, T., RAIMOND, R., JUCHAULT, P. AND SOUTY-GRosSET, C. 1993. Mitochondrial DNA polymorphism and feminizing sex factors dynamics in a natural population of Armadillidium vulgare (Crustacea, Isopoda). Genetica, 92, 55-60.

HADLEY, N. F. AND HENDRICKS, G. M. 1985. Cuticular microstructures and their relationship to structural color and transpiration in the terrestrial isopod Porcellionides pruinosus. Can. J. Zool., 63, 649-656.

JUCHAULT, P., RIGAUD, T., MOCQUARD, J. AND P. 1993. Evolution of sex determination and sex ratio variability in wild populations of Armadillidium vulgare Latr. (Crustacea, Isopoda): a case of conflict resolution. Acta Oecologica, 69, 382-390.

JUCHAUlt, P., FRELON, M., BOUCHON, D. AND RIGAUD, T. 1994. New evidence for feminizing bacteria in terrestrial isopods: evolutionary implications. C. r. Acad. Sci. Paris III, 317, 225-230.

KOCHER, T. D., THOMAS, W. K., MEYER, A., EDWARDS, S. V. AND PÄÄBO, S. 1989. Dynamics of mitochondrial DNA evolution in animals: amplification and sequencing with conserved primers. Proc. Natl. Acad. Sci. U.S.A., 86, 6196-6200.
MARTIN, G., JUCHAUlt, P. AND LEGRAND, J. J. 1973. Mise en évidence d'un microorganisme intracytoplasmique symbiote de l'oniscoïde Armadillidium vulgare L., dont la présence accompagne l'inter sexualité ou la féminisation totale des mâles génétiques de la lignée thélygène. C. r. Acad. Sci. Paris III, 276, 2313-2316.

MAYNARD SMITH, J. AND HAIGH, J. 1974. The hitchhiking effect of a favourable gene. Genet. Res., 23, 23-35.

NEI, M. AND TAJIMA, F. 1983. Maximum likelihood estimation of the number of nucleotide substitutions from restriction sites data. Genetics, 105, 207-217.

O'NEILl, S. L., GIODANO, R., COLBERT, A. M., KARR, T. L. AND ROBERTSON, H. M. 1992. 16S rDNA phylogenetic analysis of the bacterial endosymbionts associated with cytoplasmic incompatibility in insects. Proc. Natl. Acad. Sci. U.S.A., 89, 2699-2702.

RAIMOND, R., MARCADÉ, I., BOUCHON, D., RIGAUD, T., BOSSY, J., P. AND SOUTY-GROSSET, C. 1999. Organization of the large mitochondrial genome in the Isopod Armadillidium vulgare. Genetics, 151, 203-210.

RIGAUD, T. 1997. Inherited microorganisms and sex determination of arthropod hosts. In: O'Neill, S. L., Hoffmann, A. A. and Werren, J. H. (eds) Influential Passengers: Inherited Microorganisms and Arthropod Reproduction, pp. 81-101. Oxford University Press, Oxford.

RigAUd, T., ANTOINE, D., MARCADÉ, I. AND JUCHAUlT, P. 1997. The effect of temperature on sex ratio in the isopod Porcellionides pruinosus: environmental sex determination or a by-product of cytoplasmic sex determination? Evol. Ecol., 11, 205-215.

ROUSSET, F., BOUCHON, D., PINTUREAU, B., JUCHAULT, P. AND SOLIGNAC, M. 1992. Wolbachia endosymbionts responsible for various alterations of sexuality in arthropods. Proc. $R$. Soc. B., 250, 91-98.

SIMON, C., FRANKE, A. AND MARTIN, A. 1991. The polymerase chain reaction: DNA extraction and amplification. In: Molecular Techniques in Taxonomy. NATO ASI Series. Cell Biology, 57, 329-377.

SOUTY-GROSSET, C., RAIMOND, R. AND TOURTE, M. 1992. Déterminisme épigénétique du sexe et divergence génétique de l'ADN mitochondrial chez Armadillidium vulgare Latr. (Crustacé Oniscoïde): variabilité inter et intrapopulations. C. r. Acad. Sci. Paris III, 314, 119-125.

Strouhal, H. 1938. Oniscoidea Peloponnnesi (15. Beitrag zur Landisopodenfauna des Balkans). Inst. Musei Zool. Univ. Athen., 2, 1-56.

TAM, Y. K., KORNFIELD, I., OJEDA, F. AND P. 1996. Divergence and zoogeography of mole crab, Emerita spp. (Decapoda: Hippidae), in the Americas. Mar. Biol., 125, 489-497.

TURELLI, M., HOFFMANN, A. A. AND McKECHNIE, S. W. 1992. Dynamics of cytoplasmic incompatibility and mtDNA variation in natural Drosophila simulans populations. Genetics, 132, 713-723.

VANDEL, A. 1960. Faune de France. Isopodes Terrestres (Première Partie). P. Chevalier, Paris.

VERHOEFF, K. W. 1918. Zur Kenntnis der Ligidien, Porcellioniden, und Onisciden. 24 Isopoden-Afsatz. Arch. Naturgeschichte, 82A, 108-169. 
WERREN, J. H. AND O'NEILL, S. L. 1997. The evolution of heritable symbionts. In: O’Neill, S. L., Hoffmann, A. A. and Werren, J. H. (eds) Influential Passengers: Inherited Microorganisms and Arthropod Reproduction, pp. 1-41. Oxford University Press, Oxford.
WILSON, A. C., CANN, R. L., CARR, M. G., GYLLENSTEN, U. B., HELMBYCHOWSKI, M., HIGUSHI, R. G., ET AL. 1985. Mitochondrial DNA and two perspectives on evolutionary genetics. Biol. J. Linn. Soc., 26, 375-400. 